\title{
APPLICATION OF BEKONANG CLAY AND ANDISOL SOIL COMPOSITES AS COPPER (II) METAL ION ADSORBENT IN METAL CRAFTS WASTEWATER
}

\author{
Pranoto Pranotoo, ${ }^{1, *}$, C. Purnawan ${ }^{1}$ and T. Utami ${ }^{1}$ \\ ${ }^{1}$ Department of Chemistry, Sebelas Maret University, Surakarta-57126, Indonesia \\ *E-mail : pakpranotomipa@staff.uns.ac.id
}

\begin{abstract}
The utilization of bekonang clay and andisol soil composite as the adsorbent of $\mathrm{Cu}$ (II) metal ion has been studied. The aims of this study were to determine the optimum conditions of adsorption including $\mathrm{pH}$ of the copper solution, adsorbent calcination temperature, composite composition, adsorbent contact time, and their adsorption capacity in metal craft wastewater. Bekonang clay was activated with $1.5 \mathrm{M} \mathrm{H} 2 \mathrm{SO} 4$ and andisol soil with $3 \mathrm{M} \mathrm{NaOH}$. Experiment of adsorption on $\mathrm{Cu}(\mathrm{II})$ metal ion was performed at $\mathrm{pH}$ solution of 1, 2, 3, 4, 5, 6, 7, and 8, calcination temperature of 100, 200, 300 and $400{ }^{\circ} \mathrm{C}$, variation of composition bekonang clay and andisol soil composite of 100:0, 25:75, 50:50, 75:25, and 0:100 (w/w) and contact time of 15, 30, 60, and 90 minutes in the batch system. Measurement of final concentration at equilibrium was conducted using AAS. The optimum condition of copper(II) metal ion adsorption was obtained at $\mathrm{pH} 6$, calcination temperature $400{ }^{\circ} \mathrm{C}$, bekonang clay and andisol soil composition 25:75 (w/w), contact time 30 minutes with adsorption capacity by $0.37 \mathrm{mg} / \mathrm{g}$. Adsorption isotherm followed Langmuir and Freundlich isotherm. Adsorbent adsorption capacity in the metal crafts wastewater was $17.38 \mathrm{mg} / \mathrm{g}$.
\end{abstract}

Keywords: Bekonang Clay, Andisol Soil, Copper, Adsorption.

(C) RASĀYAN. All rights reserved

\section{INTRODUCTION}

Rapid industrial growth in Indonesia is not only bringing positive impacts but also has a negative impact on the environment. The negative impact is that more industrial waste disposal containing hazardous chemicals is produced. Among these harmful chemicals are heavy metals. Heavy metals are usually used as raw materials as well as supporting materials in the industry. Metalcraft industry is one of the industries producing wastewater containing quite a lot of heavy metals. The metals include copper $(\mathrm{Cu})$, nickel $(\mathrm{Ni})$, chromium $(\mathrm{Cr})$, lead $(\mathrm{Pb})$, cadmium $(\mathrm{Cd})$ and zinc $(\mathrm{Zn})$ metals. ${ }^{1}$ Based on Sekarwati et al. ${ }^{2}$, metal craft wastewater in Kotagede, Yogyakarta contained $\mathrm{Cu}$ metal ion by $84.93 \mathrm{mg} / \mathrm{L}$. According to U.S. Environmental Protection Agency (EPA), maximum ion content of $\mathrm{Cu}$ (II) in industrial waste is $1.3 \mathrm{mg} / \mathrm{L} .^{3}$ The presence of high concentrations of $\mathrm{Cu}$ (II) metal ions in the body can lead to health problems and even death. ${ }^{4}$ Some methods employed to reduce the $\mathrm{Cu}$ (II) metal ions in wastewater are included chemical precipitation, ion exchange, coagulation, and adsorption ${ }^{4}$. Adsorption is one of the most commonly applied methods since the material is easy to obtain, low cost, effectively reducing pollutants to low concentrations and enabling regeneration and reuse. ${ }^{5}$ Adsorption is a phenomenon whereby a substance attaches on another substance surfaces. The amount of at least adsorbed substance depends on the surface area of the adsorbent and its active groups. According to Gil et al. ${ }^{6}$, the soil is a type of adsorbent which it is widely available and cheap. Based on previous research, soil minerals were developed as adsorbents of inorganic and organic compounds. Activated sarooj clay was able to adsorb metals $\mathrm{Zn}, \mathrm{Cd}$, and $\mathrm{Pb}$ by $26.19 \%, 34.63 \%$, and $67.15 \%$, respectively at $\mathrm{pH} 5$ with 3 hours contact time. ${ }^{7}$ The natural clay can also adsorb Cu (II) ions of $68.70 \%$ with 120 minutes of a contact time. ${ }^{8}$

In Indonesia, clay is usually only utilized as raw material for making tile, brick, and clay craft. Clay has great potential as an adsorbent because of its abundant presence, a large surface area with active groups such as silanol and aluminol in its skeletal structure and easily dispersed in water. The active group may interact with positively charged metal ions. ${ }^{9,10}$ However, natural clay without initial treatment applied as an

Rasayan J. Chem., 11(1), 23-31(2018)

http://dx.doi.org/10.7324/RJC.2018.1111939 
adsorbent gives less than maximum yield. The natural clay is enhanced its activity both physically and chemically. In this study, clays were activated with a solution of $1.5 \mathrm{M} \mathrm{H}_{2} \mathrm{SO}_{4}$ and added andisol soil. It was reviewed by Bradl ${ }^{11}$ that clays have the good ability as well as effectively removal such metal ions since they have the high cationic exchange capacity and specific adsorption ability. Additionally, soil provides a large number of functional group and high cationic exchange capacity either. By combining both of this nature, consequently, will generate an adsorbent with good ability to adsorb the metal ion.

Andisol soil is a volcanic ash soil that is often found in areas with an altitude of about 700-1500 m above sea level and the former volcano. Andisol soils have high organic content, high cationic exchange capacity containing a high amount of allophane. ${ }^{12}$ Andisol soils have distinctive properties assumed that they are closely related to the high content of allophane. When wet, the soil is polished (smeary). Physical properties are changed with changes in water content. When they are dry, andisol soils will be difficult to absorb water again and will produce black clumps that are less dispersed in water. Several studies have shown that andisol soils have high surface area with active functional groups that are amphoteric in nature which capable to absorb both cationic and anionic adsorbate. ${ }^{13}$ Especially in Indonesia, andisol soils containing allophane is abundant and widely available in Lawu Mountain. ${ }^{14}$

In this study, the making of clay and soil andisol composites as an adsorbent of $\mathrm{Cu}$ (II) metal ions and determination of optimum conditions of $\mathrm{Cu}$ solution $\mathrm{pH}$, calcination temperature, adsorbent composite ratio and adsorption contact time as well as its application on metal handicraft wastewater have been conducted. The clay and soil clay composites are expected to have better properties as adsorbents which are readily dispersed in water and high adsorption capacity so as to reduce waste pollution generated by the metal craft industry.

\section{Material and Methods}

\section{EXPERIMENTAL}

The instruments and apparatus used in this research were atomic adsorption spectrometer (AAS, Perkin Elmer Analyst 700), Fourier transform infrared spectroscopy (FTIR, Shimadzu 8201 PC), x-ray diffraction (XRD, Shimadzu 6000), analytical balance (Sartorius BP 110), pH meter (Eutech Instrument pH 700), ultrasonicator (71020-DTH-E, model 1510 dTH 220V), shaker (Mitamura Riken), and glass tools (Pyrex dan Duran). Andisol soil (Cemoro Kandang, Lawu Mountain), Bekonang clay (Sukoharjo, Indonesia), wastewater (Kotagede, Yogyakarta), $\mathrm{H}_{2} \mathrm{SO}_{4}$ p.a (E-Merck), distilled water, $1000 \mathrm{mg} / \mathrm{L}$ of $\mathrm{Cu}$ standard solution (E-Merck), $\mathrm{HNO}_{3}$ p.a (E-Merck), $\mathrm{CH} 3 \mathrm{COOH}$ p.a (E-Merck), $\mathrm{HCl}$ p.a (E-Merck), $\mathrm{CH}_{3} \mathrm{COONa}$ (EMerck), $\mathrm{NaOH}$ (E-Merck) and $\mathrm{KCl}$ (E-Merck) were employed in this study.

\section{Preparation of Composite}

The initial treatment of bekonang clay and andisol soil was performed in this study. The bekonang clay was activated using $1.5 \mathrm{M} \mathrm{H}_{2} \mathrm{SO}_{4}$ while andisol soil employed $3 \mathrm{M} \mathrm{NaOH}$ to activate it. Activated samples were characterized by FTIR and XRD. The composition of bekonang clay and andisol soil adsorbent was varied by 100:0, 25:75, 50:50, 75:25, and 0:100 (w/w). The composites were prepared using sonication treatment for $1 \mathrm{~h}$ under constant stirring. The resulted composites were filtered and dried in an oven at $105{ }^{\circ} \mathrm{C}$ for 4 hours.

\section{Optimization of pH}

A total of 0.05 grams of bekonang clay and andisol soil 50:50 (w/w) were introduced into a beaker containing $10 \mathrm{~mL}$ of $3 \mathrm{ppm} \mathrm{Cu}$ solution with buffer $\mathrm{pH}$ variation of 1, 2, 3, 4, 5, 6, 7 and 8. The solution was shaken for 30 minutes, filtered and the filtrate was measured using AAS.

\section{Optimization of Adsorbent Calcination Temperature}

The clay and soil composites ratio of 50:50 (w/w) was calcined at 100, 200, 300, and $400{ }^{\circ} \mathrm{C}$ for 3 hours. About $0.05 \mathrm{~g}$ of each calcined composites were added to the beaker containing $10 \mathrm{~mL}$ of $3 \mathrm{ppm} \mathrm{Cu}$ solution adjusted at optimum $\mathrm{pH}$ condition. The solution is shaken for 30 minutes, filtered and the filtrate was measured using AAS. 
RASĀYAN J. Chem.

Vol. 11 | No. 1 |23-31 | January - March | 2018

\section{Optimization of Adsorbent Composition and Contact Tima}

A total of 0.075 grams of each bekonang clay and andisol soil composite at a ratio of 100: 0, 25:75, 50:50, 75:25, and 0:100 (optimum calcination temperature) were introduced into $10 \mathrm{~mL}$ of $3 \mathrm{ppm} \mathrm{Cu}$ solution (pH Optimum). The mixture was shaken by varying the adsorption contact time by 15, 30, 60 and 90 minutes. Afterward, the mixture was filtered and analyzed using AAS.

\section{Adsorption Isotherm}

A total of 0.075 grams of the bekonang clay and andisol soil composite at best conditions were added to 10 $\mathrm{mL}$ of varied $\mathrm{Cu}$ solution $(2,4,6,8,10$ and $12 \mathrm{ppm})$. The mixture was shaken at optimum contact time. Then, the mixture was filtered and analyzed by AAS.

\section{Determination of $\mathbf{C u}(\mathrm{II})$ Adsorption Capacity in Wastewater}

A total of $100 \mathrm{~mL}$ of wastewater was introduced into the beaker, destructed with $5 \mathrm{ml}$ of concentrated HNO3 solution to the remaining solution $\pm 10 \mathrm{~mL}$. The destructed solution was filtered and tested by using AAS. A total of $25 \mathrm{~mL}$ of wastewater is neutralized with $1 \mathrm{M} \mathrm{NaOH}$ solution to optimum $\mathrm{pH}$. Then, $10 \mathrm{~mL}$ of solution was taken and added with 0.075 grams of the bekonang clay and andisol soil. The adsorption was performed in optimum condition. The filtrate was collected and measured using AAS.

\section{FTIR Analysis}

\section{RESULTS AND DISCUSSION}

The IR spectra of active bekonang clay, active andisol soil and the composite are shown in Fig.-1. It can be seen in the Fig.-1 that the active group of the bekonang clay and andisol soil composite is same with the active group of either bekonang clay and andisol soil. However, there are some peaks that shift and involving intensity changes after they are composed. It indicated an interaction between clay and soil occurred. Andisol soil will be attached to the clay due to the nature of clay. Based on the IR spectra of the composites reveals the absorbance band around $3442 \mathrm{~cm}^{-1}$ and $1644 \mathrm{~cm}^{-1}$ assigned to the $\mathrm{OH}$ vibration band. It also found the absorbance band at 1004 corresponds to O-Si-O or O-Al-O, whereas the absorbance band at $733-431 \mathrm{~cm}^{-1}$ is characteristic of $\mathrm{Si}-\mathrm{O}$ and $\mathrm{Al}-\mathrm{O}$ vibration.

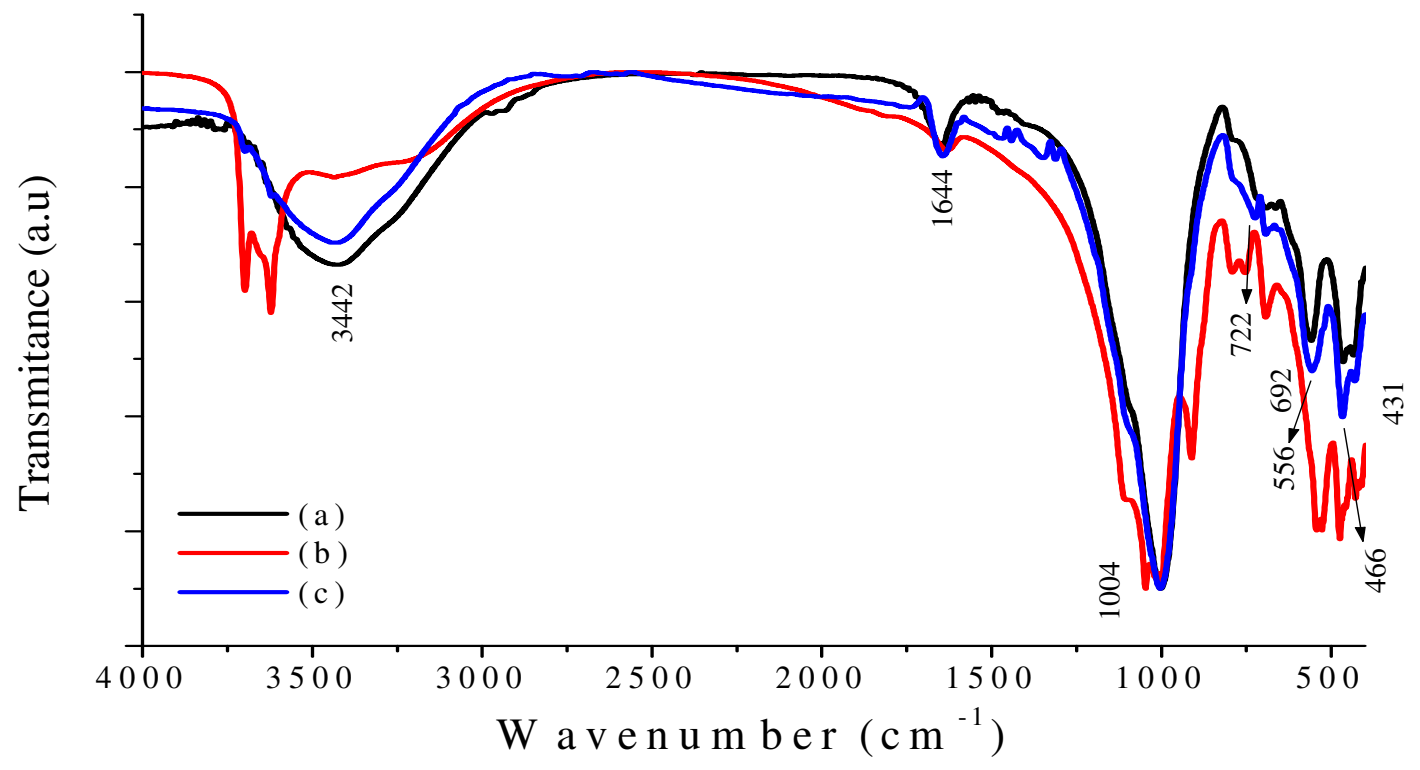

Fig.-1: IR spectra of (a) Active Andisol Soil, (b) Active Bekonang Clay, and (c) Bekonang and Andisol Soil

\section{XRD Analysis}

Composites (25:75)

The XRD analysis results of the activated bekonang clay, andisol soil and the composite are shown in Fig.2. As seen in the Fig.-2 that the intensity of the minerals peaks changes after the bekonang clay and andisol 
soil were composed. The high intensity correlates to an increase of the minerals crystal planes number in the composites. Clearly, the increased intensities occur at $2 \theta 8.14^{\circ}, 27.30^{\circ} .66 .60^{\circ}$ (allophane); $9.78^{\circ}$. $27.30^{\circ}, 42.56^{\circ}$ (montmorillonite); $24.88^{\circ}, 26.02^{\circ}, 34.90^{\circ}, 35.92^{\circ}$ (kaolinite); $19.90^{\circ}, 27.30^{\circ}$ (illite); $24.34^{\circ}$, $26.48^{\circ}, 50.50^{\circ}$, and $59.98^{\circ}$ (quartz); as well as $24.62^{\circ}, 27.30^{\circ}, 34.48^{\circ}$ (feldspar).

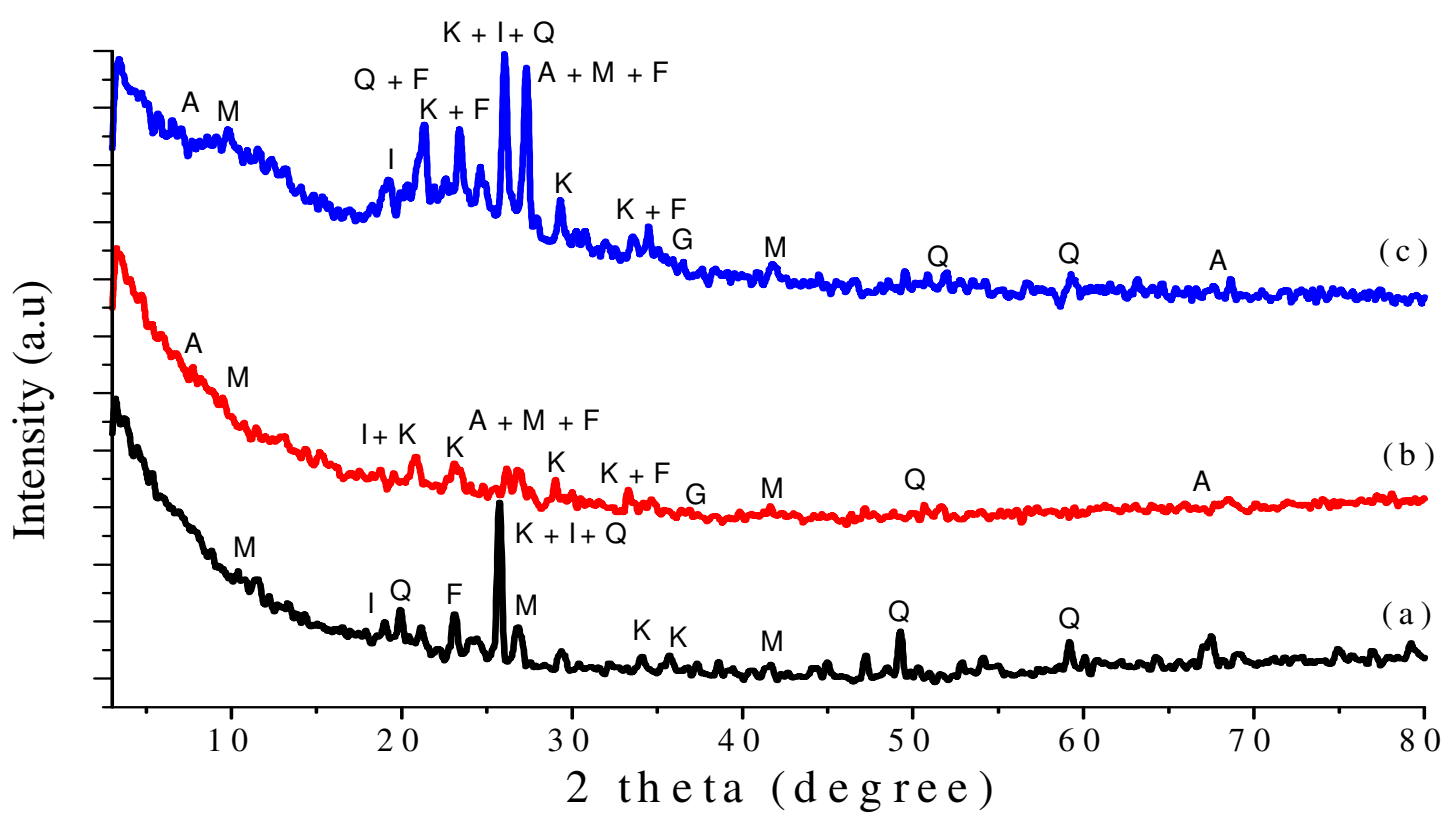

Fig.-2: XRD Diffractograms of (a) The Activated Bekonang Clay, (b) Activated Andisol Soil, and (c) The Bekonang Clay and Andisol Soil Composite (25:75)

\section{Determination of Optimum Condition}

Optimization of $\mathrm{pH}$ conditions was performed under $\mathrm{pH}$ 1-8 for 30 minutes. Variations of $\mathrm{pH}$ 1-8 are used to determine the effect of $\mathrm{pH}$ on acid, neutral and base conditions toward the adsorbent ability. The test results of the $\mathrm{pH}$ effect on the adsorption capacity of $\mathrm{Cu}$ solution are presented in Fig.-3.

Generally, the higher of $\mathrm{pH}$ applied in the adsorption will result in higher adsorption capacity. However, in practical observation, the $\mathrm{Cu}$ (II) ion begun to settle when it reached $\mathrm{pH}>7$ indicated by obtaining a bluish white precipitate. Consequently, the initial concentration could be decreased. In other words, it was possible that the initial concentration of solution at $\mathrm{pH}>7$ smaller than $\mathrm{pH}$ 1-6. However, in this work, we did not measure the precise concentration of solution at $\mathrm{pH}>7$. In addition, the surface of adsorbent was easy to protonate at the alkaline $\mathrm{pH}$ solution providing sites to adsorb the remains $\mathrm{Cu}$ (II) ions. However, it should be noted that the not only high adsorption capacity should be considered, but also the adsorption optimum condition defined as a condition that adsorbent optimally adsorbs the $\mathrm{Cu}$ solution containing a large number of $\mathrm{Cu}$ (II) species. According to Pourbaix $\mathrm{Cu}$ /water diagram, $\mathrm{Cu}(\mathrm{II})$ ion species are obtained at $\mathrm{pH}$ 1-6.25. More than $\mathrm{pH}$ 6.25, it has already begun to form $\mathrm{Cu}$ oxide. This is stated by Sajidu et al. ${ }^{15}$ which at a $\mathrm{pH}$ more than 6.28 , the $\mathrm{Cu}$ metals will begin to precipitate into $\mathrm{Cu}(\mathrm{OH})_{2}$. Therefore, the optimum $\mathrm{pH}$ condition to adsorb $\mathrm{Cu}$ (II) ions was concluded at $\mathrm{pH} 6$.

The $\mathrm{pH}$ conditions also affect the charge on the adsorbent surfaces which interacts with $\mathrm{Cu}$ (II) ions and their adsorption capacity. At low pH (acid), the adsorption capacity tends to be smaller because the surface will tend to receive protons resulted in positively charged surfaces. Consequently, the repulsive forces between adsorbent surfaces and the $\mathrm{Cu}^{2+}$ ion will have occurred. At a neutral $\mathrm{pH}$, the adsorbents containing the aluminol and silanol groups which both of them release protons $\left(\mathrm{H}^{+}\right)$so that the surface is negatively charged providing a good site to adsorb $\mathrm{Cu}^{2+}$ more effectively. Moreover, the solution $\mathrm{pH}$ condition will also affect the degree of competition between protons $\left(\mathrm{H}^{+}\right)$and $\mathrm{Cu}^{2+}$ ions attaching in the adsorbent. 
RASĀYAN J. Chem.

Vol. 11 | No. 1 |23-31 | January - March | 2018

The optimization of the calcination temperature was carried out at a temperature of $100-400{ }^{\circ} \mathrm{C}$ and the solution was conditioned to $\mathrm{pH} 6$. This treatment was conducted to remove the residual impurities and water contained in the adsorbent, so it is expected that the surface area and pores will increase so that the interaction between adsorbate and the adsorbent is more effective. The release of a hydrated water molecule is required at higher temperatures $\left(400-500{ }^{\circ} \mathrm{C}\right)$. However, a higher activation temperature than the optimum temperature of the adsorbent above $500{ }^{\circ} \mathrm{C}$ causing the adsorbent to lose much mass and its structure begins to break down ${ }^{16}$. The temperature optimization test data is presented in Fig.-4.

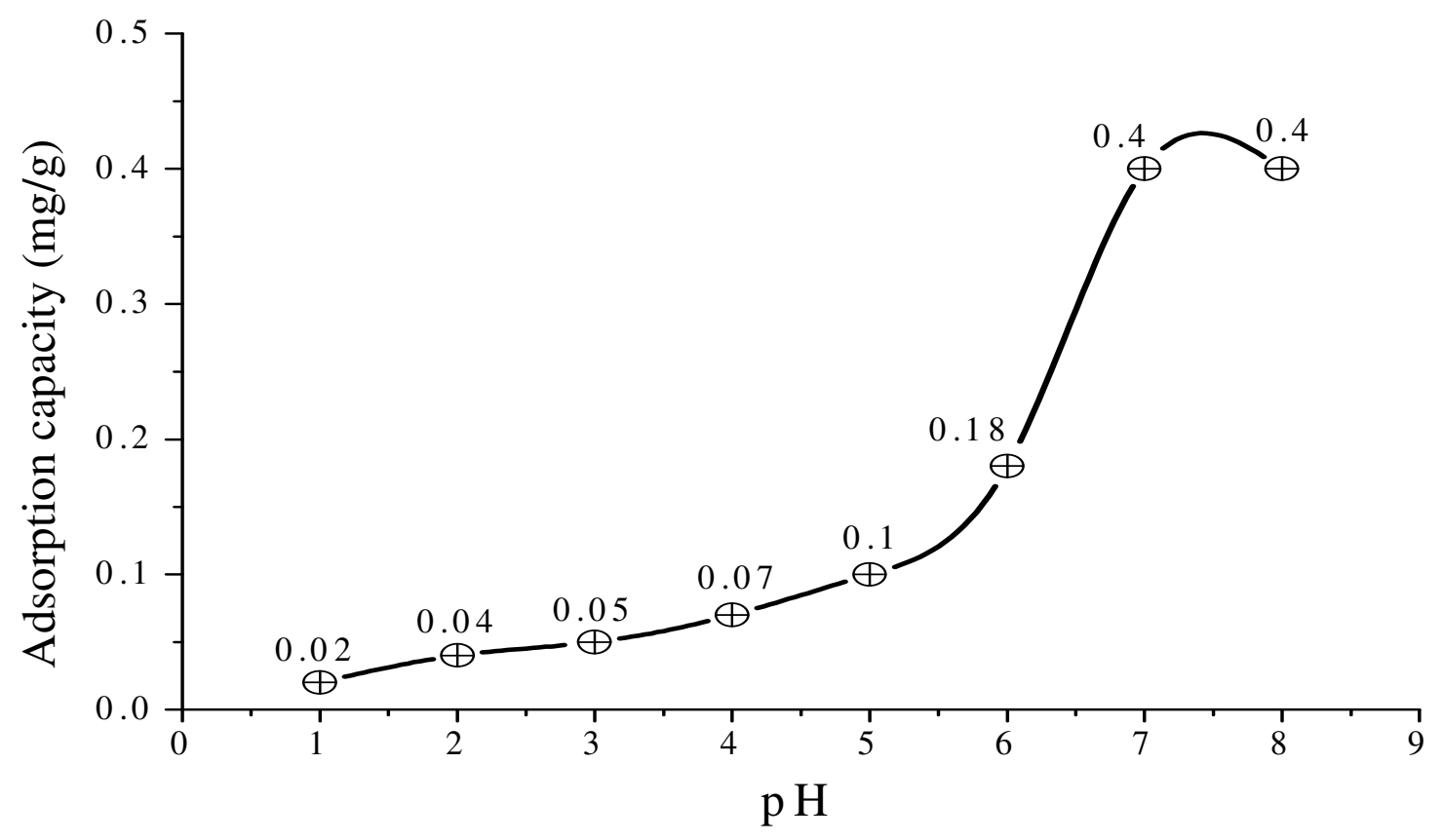

Fig.-3: Graphic of the pH effect toward adsorbent adsorption capacity

As revealed in Fig.-4, it can be seen that the calcination temperature has a great impact on the adsorption ability of materials. The higher of calcination temperature gave high values of adsorption capacity. In this study obtained the optimum temperature condition by $400{ }^{\circ} \mathrm{C}$. Accordingly, the calcination temperature is one of the key parameters influencing the structural as well as the surface area of the material. By increasing of calcination temperature until optimum condition will dramatically enhance the surface area of material as studied by Amadine et al. ${ }^{17}$. Therefore, the adsorption ability of material will be enhanced as a result of surface area improvement. In this study, we applied calcination temperature by $400{ }^{\circ} \mathrm{C}$ to prevent the structural defect which it straightly affected the surface area. It was mentioned by Yu et al. ${ }^{18}$ that the higher of calcination temperature over the optimum condition gave a decreasing on the surface area. Thus, we proposed that at the optimum temperature gave an optimum adsorption ability which possible due to the impurities and water molecules will be more liberated at the higher calcination temperature affecting the increase of surface area. In another word, the adsorption will be more optimal.

The optimization of composite compositions and contact time were performed under an optimum $\mathrm{pH}$ condition ( $\mathrm{pH} \mathrm{6)}$ by varying the contact time by 15, 30, 60, and 90 minutes and the compositions of the bekonang clay and andisol soil by 100:0; 75:25; 50:50; 25:75; 0:100 (w/w) calcined at $400{ }^{\circ} \mathrm{C}$. The test results of the adsorption capacity of each composites composition and at the variation of contact time are shown in Fig.-5.

Based on Fig.-5, it can be seen that the optimum condition of the adsorbent ratio to adsorb the $\mathrm{Cu}$ (II) metal ions is obtained at 25:75 (w/w) composites composition, whereas the optimum contact time is 30 minutes with adsorption capacity $0.37 \mathrm{mg} / \mathrm{g}$ and percentage absorption by $99.08 \%$. From the test results showed that the adsorption is strongly influenced by andisol soil ratio where by adding a high concentration of andisol soil to the composites gave high adsorption capacity. This is possible since the composite at 25:75 
RASĀYAN J. Chem.

Vol. 11 | No. 1 |23-31 | January - March | 2018

(w/w) ratio can be well dispersed in solution and probably having a large surface area. So that, the interaction between its active group and $\mathrm{Cu}$ (II) metal ions will be greater.

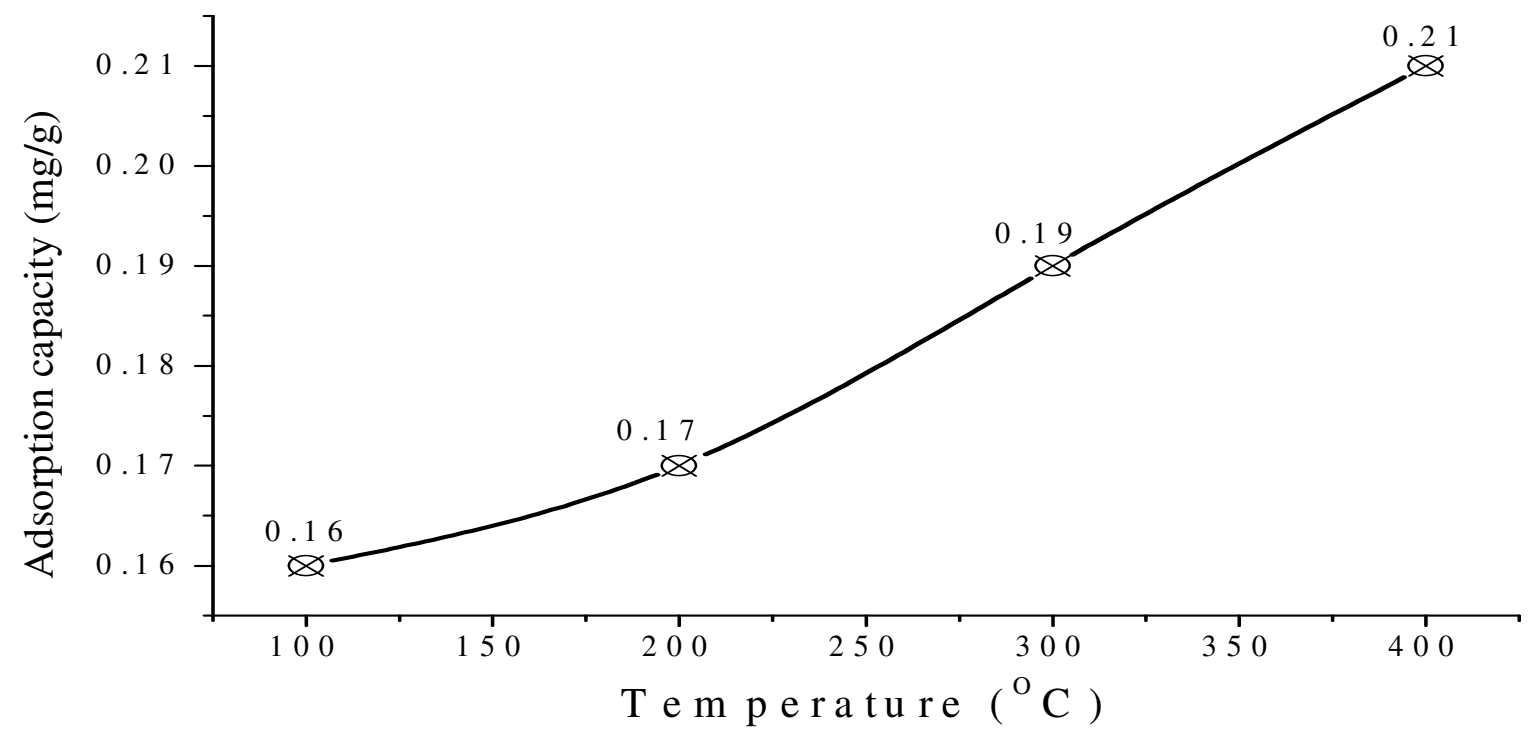

Fig.-4: Graphic of the temperature effect on the adsorbent adsorption capacity

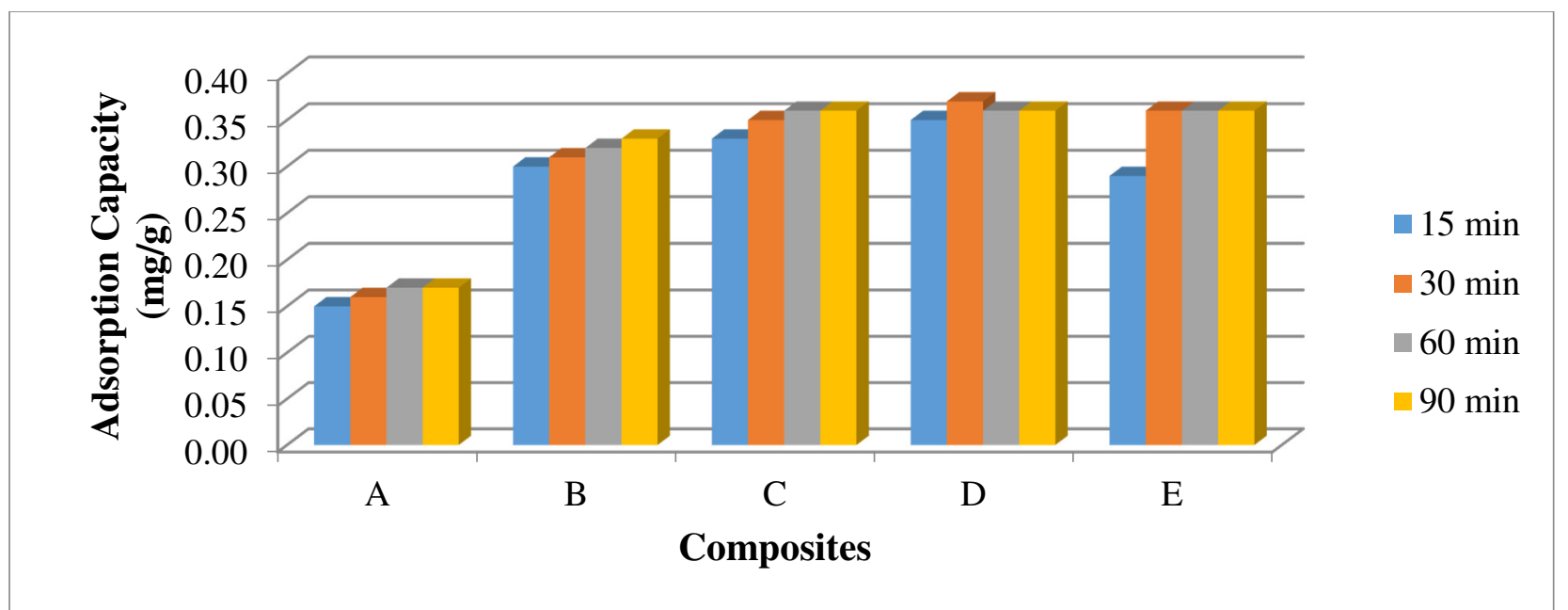

Fig.-5: Graphic of ratio and contact time effect on the adsorbent adsorption capacity (Note: Composition of bekonang clay and andisol soil $(\mathrm{A}=100: 0, \mathrm{~B}=75: 25, \mathrm{C}=50: 50, \mathrm{D}=25: 75, \mathrm{E}=0: 100)$

As of the obtained data showed that the adsorption of $\mathrm{Cu}$ (II) metal ions onto the bekonang clay and andisol soil composites at ratio 25:75 start to equilibrium at 30 minutes of contact time. In other composite compositions, the adsorption of $\mathrm{Cu}$ (II) metal ions tends to be constant at contact time between 30-90 minutes.

\section{Adsorption Isotherm Study}

Composite of bekoang clay and andisol soil at ratio 25:75 have the ability to interact with $\mathrm{Cu}$ (II) metal ions both chemically and physically. The analysis was performed using Langmuir and Freundlich isotherms method. The determination of the isotherm is based on the $\mathrm{R} 2$ value in the $\mathrm{Cu}$ solution concentration range by 2-12 ppm. Langmuir and Freundlich isotherm curves for $\mathrm{Cu}$ (II) metal ions can be seen in Figs.-6 and 8 . 
RASĀYAN J. Chem.

Vol. 11 | No. 1 |23-31 | January - March | 2018

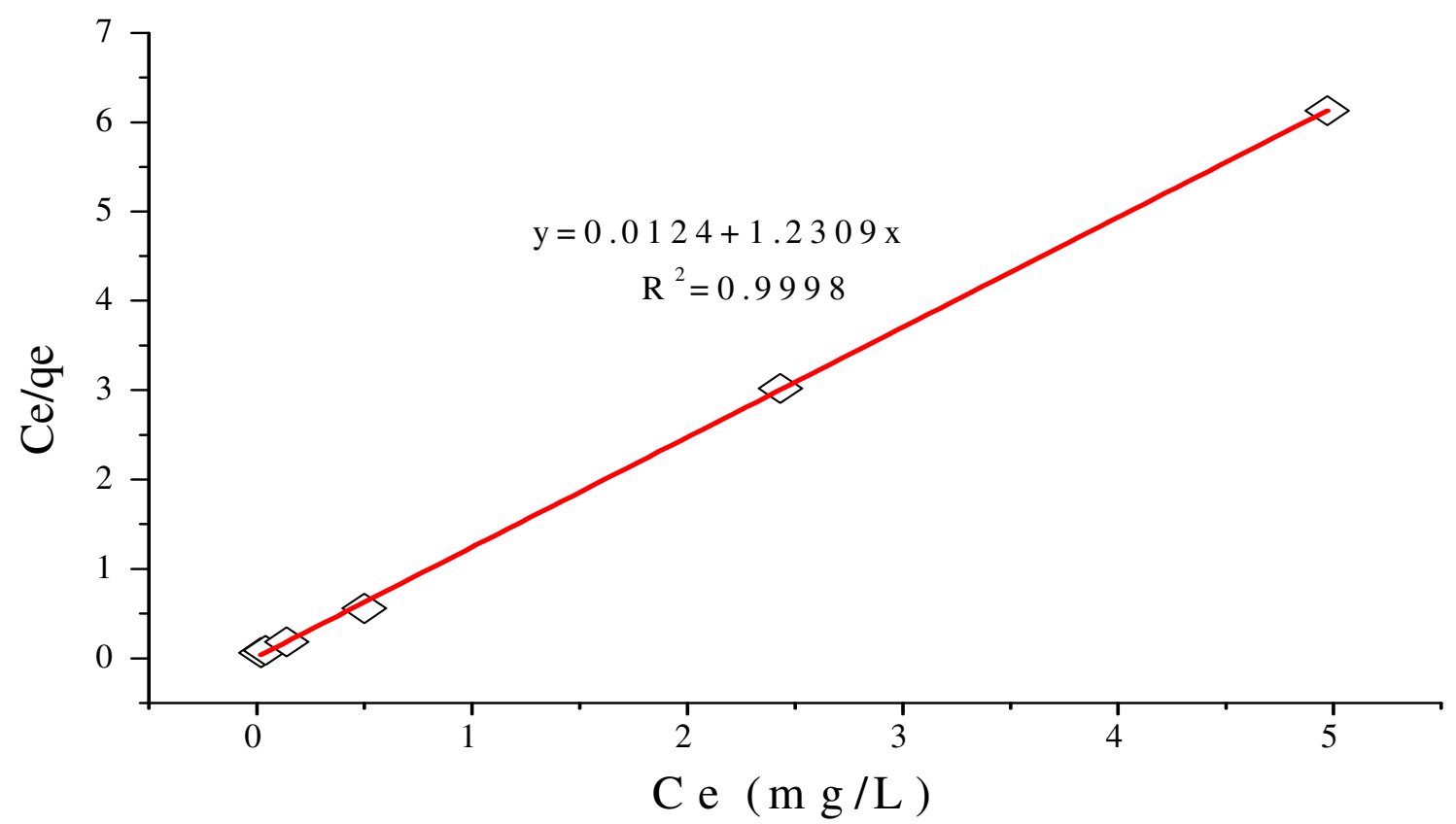

Fig.-6: Langmuir isotherm model

Langmuir isotherms show that the adsorption process between adsorbent and adsorbate chemically occurs to form a monolayer. ${ }^{19}$ From Fig.-6, the value of $\mathrm{R}^{2}$ close to 1 , precisely the $\mathrm{R}^{2}$ value is 0.9998 indicating that the adsorbent active group interacts with $\mathrm{Cu}$ (II) metal ion through a chemical bond. Possible reactions that occur when the adsorption process is shown in Fig.-7.

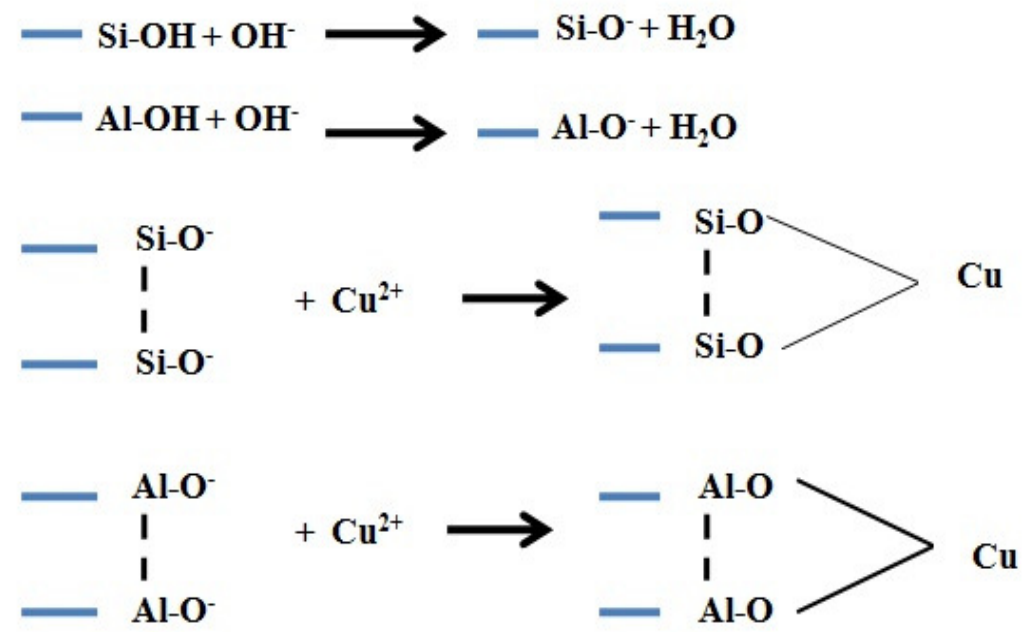

Fig.-7: Adsorption reaction of $\mathrm{Cu}(\mathrm{II})$ metal ion with the adsorbent ${ }^{20}$.

The Freundlich plot graph is shown in Fig.-8 generating $\mathrm{R}^{2}$ value by 0.6598 . This indicates that the adsorption of $\mathrm{Cu}$ (II) metal ions also occurs physically through van der Waals forces. The van der Waals force occurs hence the surface of the electronegative adsorbent interacts with the electrolytic $\mathrm{Cu}$ (II) metal ion, although the interaction is weak. This weak repulsive force causes the adsorbate to move from one point of the adsorbent surface to another surface forming a multilayer. ${ }^{21}$

Based on the calculation, the adsorption capacity of adsorbent on Langmuir isotherm is $0.81 \mathrm{mg} / \mathrm{g}$ and Freundlich isotherms of $0.76 \mathrm{mg} / \mathrm{g}$ in the $\mathrm{Cu}$ solution concentration range of $\mathrm{Cu} 2-12 \mathrm{ppm}$. 


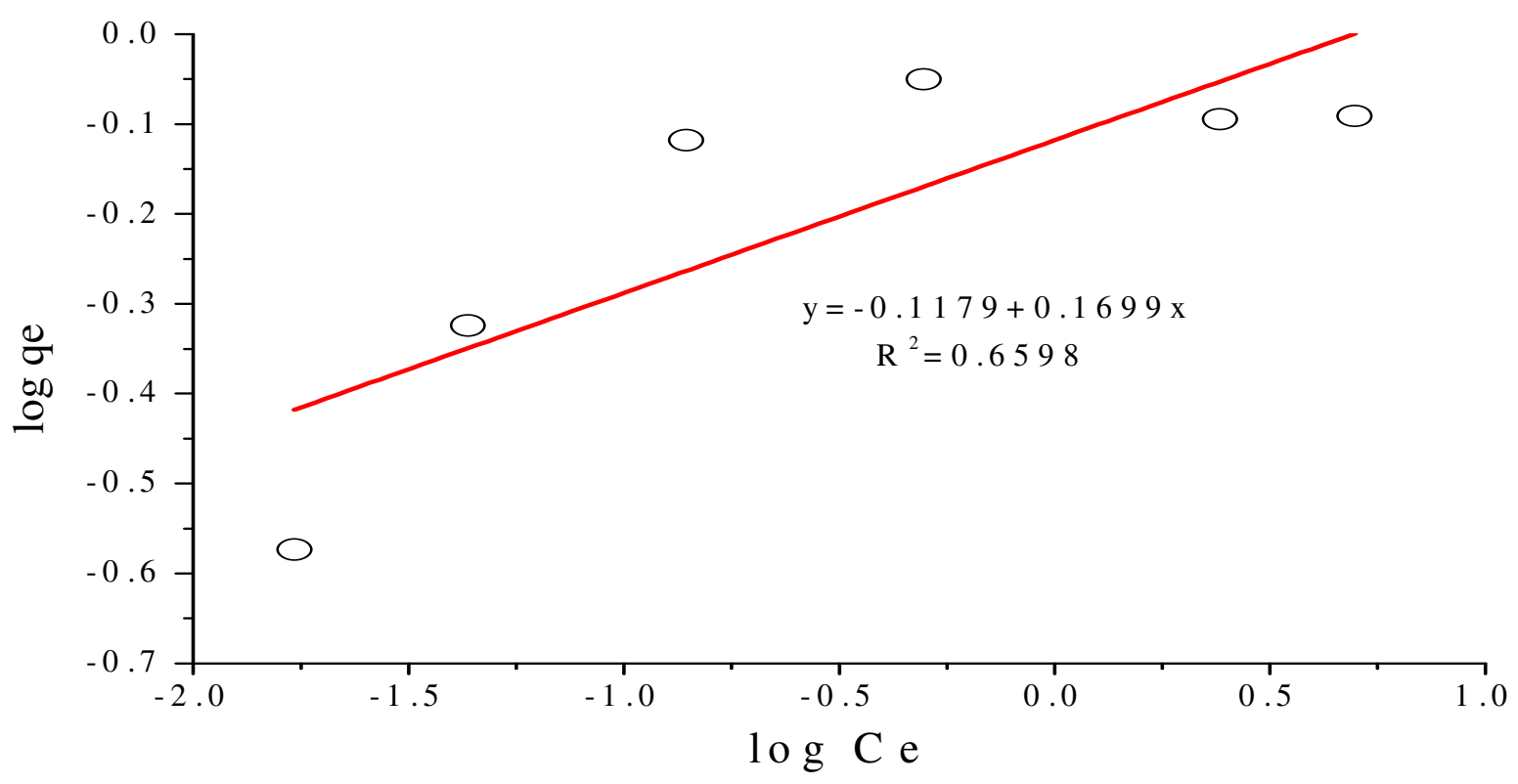

Fig.-8: Freundlich isotherm model

\section{Adsorption Capacity of $\mathrm{Cu}(\mathrm{II})$ ion on wastewater}

Based on the testing results of metal craft wastewater is obtained the copper metal content $(\mathrm{Cu})$ of 656.58 ppm. The copper metal content greatly exceeds the threshold if it is directly throw away into the environment without first processing to reduce the $\mathrm{Cu}$ content, where the standard quality is $0.60 \mathrm{ppm}$.

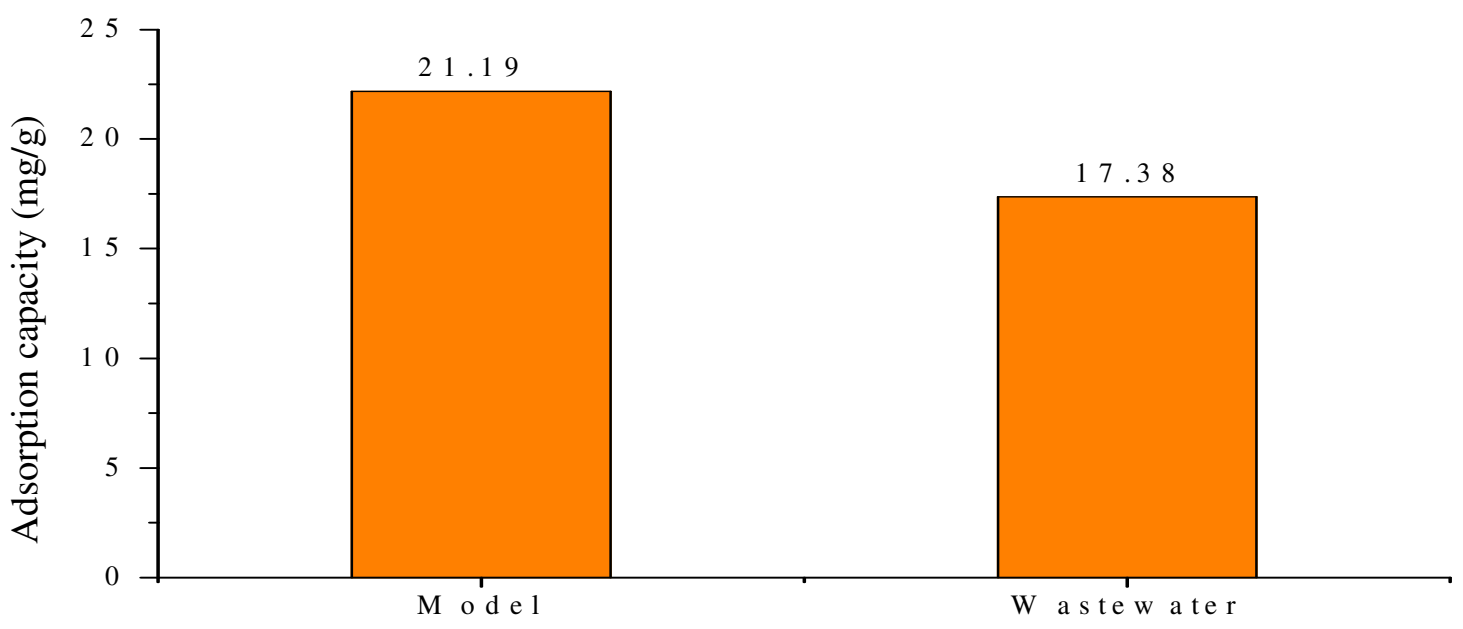

Fig.-9: Adsorption capacity comparison of $\mathrm{Cu}(\mathrm{II})$ metal ion on model and wastewater solution

The wastewater has an acidic $\mathrm{pH}$ of 1 , so it is necessary to adjust its $\mathrm{pH}$ conditioning before it is adsorbed. The conditioning of the $\mathrm{pH}$ was carried out with $1 \mathrm{M}$ of $\mathrm{NaOH}$ solution to $\mathrm{pH}$. The $\mathrm{pH} 6$ was the optimum $\mathrm{pH}$ conditions of adsorption and that $\mathrm{pH}$ was also in accordance with DIY Governor Regulation no. 7 (2010) about the quality standard of industrial wastewater prior to throwing away to the environment that is ranged 6-9. The adsorbent adsorption capacity in adsorbing $\mathrm{Cu}$ (II) metal ions in the wastewater is compared with the adsorption capacity in the model solution as shown in Fig.-9.

From the diagram shown in Fig. 9 can be seen that adsorption capacity in adsorbing $\mathrm{Cu}$ (II) metal ions in metal craft waste is $17.38 \mathrm{mg} / \mathrm{g}$ smaller when compared in the model solution that is $22.19 \mathrm{mg} / \mathrm{g}$. This 
RASĀYAN J. Chem.

Vol. 11 | No. 1 |23-31 | January - March | 2018

occurs due to there are probably other metals contained in metal craft wastewater. The presence of other metal ions causes a competition between the metals to bind to the active groups and attach to the pores of the adsorbent surface. This causes the adsorbed $\mathrm{Cu}$ (II) metal ions to be smaller when compared to the model solution consisting of only $\mathrm{Cu}$ (II) metal ions.

\section{CONCLUSION}

Adsorbent of the bekonang clay and the andisol soil composites can adsorb the $\mathrm{Cu}$ (II) metal ion at best conditions, i.e. a conditioned solution at $\mathrm{pH} 6,400^{\circ}$ of calcination temperature, 25:75 (w/w) bekonang clay and andisol soil ratio, 30 minutes of contact time with adsorption capacity of $0.37 \mathrm{mg} / \mathrm{g}$ and an adsorption percentage of $99.43 \%$. The adsorption isotherm of the $\mathrm{Cu}$ (II) adsorbed onto the composites followed both Langmuir and Freundlich isotherm, however it was dominantly to Langmuir model. The adsorbent adsorption capacity at the best condition against $\mathrm{Cu}$ (II) metal ion in metal craft waste was $17.38 \mathrm{mg} / \mathrm{g}$ which it was smaller compared with the model solution that is $22.19 \mathrm{mg} / \mathrm{g}$.

\section{REFERENCES}

1. M.M.A. Lara, G. Blazquez, M.C. Trujillo, A. Perez and M. Calero, J. Clean. Prod., 81, 120 (2014).

2. N. Sekarwati, B. Murachman and Sunarto, Jurnal Ekosains, 7(1), 64 (2015).

3. F.L. Mi, S.J. Wu and F.M. Lin, Int. J. Biol. Macromol., 72, 136 (2015).

4. S. Vafakhah, M.E. Bahrololooma, R. Bazarganlari and M. Saeedikhani, J. Environ. Chem. Eng., 2, 356 (2014).

5. G. Qiu, Q. Xie, H. Liu, T. Chen, J. Xie and H. Li, Appl. Clay Sci., 118, 107 (2015).

6. A. Gil, F.C.C. Assis, S. Albeniz and S.A. Korili, Chem. Eng. J., 168, 1032 (2011).

7. A.S.I. Eishah, Appl. Clay Sci., 42, 201 (2008).

8. L.M. Zacaroni, Z.M. Magriotis, M.D.G. Cardoso, W.D. Santiago, J.G. Mendonça, S.S Vieira and D.L. Nelson, Food Control, 47, 536 (2015).

9. D. Ozdes, C. Duran and H.B. Senturk, J. Environ. Manag., 92, 3082 (2011).

10. M.K. Uddin, Chem. Eng. J., 308, 438 (2017).

11. H.B. Bradl, J. Colloid Interface Sci., 277, 1 (2004).

12. M.H. Beare, S.J. McNeill, D. Curtin, R.L. Parfitt, H.S. Jones, M.B. Dodd and J. Sharp, Biogeochem., 120, 71 (2014).

13. J.M. Siewe, E.D. Woumfo, P. Djomgoue and D. Njopwouo, Appl. Clay Sci., 114, 31 (2015)

14. A.H. Setyawan, Sutarno and Sugiyarto, Biodiversitas, 14(1), 1 (2013).

15. S.M.I. Sajidu, I. Persson, W.R.L. Masamba, E.M.T. Henry and D. Kayambazinthu, Water SA, 32 (4), 519 (2006).

16. F. Iyoda, S. Hayashi, S. Arakawa, B. John, M. Okamoto, H. Hayashi and G. Yuan, Appl. Clay Sci., 56, 77 (2012).

17. O. Amadine, Y. Essamlali, A. Fihri, M. Larzek and M. Zahouily, RSC Adv., 7, 12586 (2017).

18. J. Yu, J.C. Yu, W. Ho and Z. Jiang, New J. Chem., 26, 607 (2002).

19. Y. Bentahar, C. Hurel, K. Draoui, S. Khairoun and N. Marmier, Appl. Clay Sci., 119, 385 (2016).

20. A. Ghoneim, N. Matsue and T. Henmi, Int. J. Soil Sci., 1(3), 243 (2006).

21. Pranoto, Suranto, K.H. Sugiyarto and Ashadi, J. Environ. Earth Sci., 3(5), 48 (2013).

[RJC-1939/2017] 